\title{
The use of lower formalin-containing embalming solution for anatomy cadaver preparation
}

\author{
Viskasari P. Kalanjati, Lucky Prasetiowati, Haryanto Alimsardjono
}

Department of Anatomy and Histology, Faculty of Medicine, Airlangga University, Surabaya, Indonesia

\begin{abstract}
Abstrak
Latar belakang: Adanya kekuatiran tingginya risiko negatif terhadap kesehatan teknisi, mahasiswa dan staf yang terlibat dalam pemrosesan dan penggunaan preparat cadaver anatomi yang selama ini lebih sering menggunakan larutan pengawet dengan formalin kadar tinggi (37\% formaldehyde). Dirasakan perlu pengenalan teknik pengawetan cadaver yang aman, efektif dan efisien, dengan efek risiko yang lebih rendah terhadap kesehatan yaitu dengan menggunakan larutan pengawet dengan formalin kadar rendah (5-7,5\% formaldehyde) yang akan diuraikan lebih lanjut dalam naskah ini.
\end{abstract}

Metode: Cadaver anatomi diinjeksi dengan menggunakan larutan pengawet berisi formalin kadar rendah (5-7.5\%) yang dipompa aktif melalui jalur arteria femoralis. Detil proses diuraikan lebih lanjut dalam manuskrip.

Hasil: Hasil yang didapat adalah spesimen cadaver yang lebih terang warnanya, dengan konsistensi yang lebih kering namun tetap lembab tanpa adanya pertumbuhan jamur sehingga struktur anatomi pada cadaver lebih jelas digunakan sebagai bahan pembelajaran.

Kesimpulan: Larutan embalming dengan kadar formalin yang lebih rendah tetap dapat menghasilkan kualitas cadaver yang baik dibandingkan dengan penggunaan larutan embalming dengan kadar formalin yang jauh lebih tinggi. (Med J Indones. 2012;21:203-7)

\begin{abstract}
Background: We used cadaver embalming technique with a high concentration of formaldehyde ( $37 \%$ formaldehyde). However, it gives toxic effects which can endanger the technicians, lecturers and students. For that reason, the effective, efficient and safer embalming process is needed; in this article we describe the use of low formalin solution (5-7.5\% formaldehyde) to achieve prior purposes.
\end{abstract}

Methods: Cadaver is embalmed by actively pumping low formalin-containing solution (5-7.5\%) via femoral arteries. Further methods are detailed in this manuscript.

Results: Paler cadaver with more intact and easier to dissect specimen (drier and still moist with no fungal growth) was resulted by using this low formalin technique.

Conclusion: The use of low formalin-containing solution in cadaver embalming gave good quality results for anatomy teaching. (Med J Indones. 2012;21:203-7)

Keywords: Anatomy specimen, cadaver preparation, low formaldehyde solution

Cadaver is an excellent medium for medical students to learn regional and topographic anatomy structures including vessels, nerves and muscles of human body. Successful cadaver embalming process for anatomy teaching, will produce cadaver with: (1) good organs and tissue preservation with minimal structural changes; (2) limited growth of fungal and bacteria; (3) low toxic effect (from the formaldehyde and phenol used in embalming solution) for the staff, students and others whom related to the cadaver and its preparations; (4) natural colour of the organ and tissues (it will not become 'browning') due to minimal oxidation effect. ${ }^{1}$

Two most common techniques used in cadaver preparation are plastination and formalin embalming process. Embalming process with formalin has been found since a long time ago but it was not used until the last period of the nineteenth century. ${ }^{2}$ The plastination technique is a good technique for producing a representative cadaver. However in developing countries, due to the humidity tropical weather also the availability of expensive equipments to preserve the cadaver, this technique is difficult to do in a routine condition.

The plastination technique was developed by Von Hagen in the 1979. ${ }^{3}$ It preserves the whole body (and organ) by using a curable polymer, which will replace the water and fat from the body tissue whilst becoming hardened. ${ }^{4}$ The plastination method consists of four fundamental steps: fixation, dehydration, forced impregnation in a vacuum and gas curing. ${ }^{5}$ In plastination, the body is fixed by immersing in $5 \%$ formalin for several days then immersed under the running water to remove the formalin excess. ${ }^{6}$ The body is kept in a freezer at $5^{\circ} \mathrm{C}$ overnight to prevent the forming of ice crystal then dehydrated by freezed substitution in $-25^{\circ} \mathrm{C}$ to eliminate the tissue water and some lipids. ${ }^{3}$ The dehydration process is completed, when the total water concentration less than $1 \%$. The 
third step is putting the body into the vacuum chamber at $-25^{\circ} \mathrm{C}$ using Biodur S-10/S-3. It is called forced impregnation, which is followed by the gas curing procedure to harden the body.

In our department, we used formalin-phenol solution with high concentration of formalin ( $37 \%$ formaldehyde by volume). In this volume, the toxic effect to lecturers, technicians and students whilst processing and dissecting the cadavers comes from inhaling the formaldehyde emission of aqueous solution. It crosses the threshold for irritation of eyes and upper respiratory tract. $^{7}$ Toxic effects of exposure to formaldehyde can be classified as irritation of mucous membrane, contact dermatitis and mutagenic or carcinogenity. ${ }^{7}$

Due to the health and safety problem as side effects of using $37 \%$ formaldehyde embalming solution, an alternative cadaver preparation by low formalin technique is conducted in our laboratory, which details will be discussed in the following paragraphs as a laboratory technique report conducted in our Department.

\section{METHODS}

All cadavers were obtained from the Department of Forensic and Medicolegal, Faculty of Medicine, Airlangga University, Surabaya, Indonesia. All procedures are done accordingly to the Ethic Committee approval and policy of Faculty of Medicine, Airlangga University.

\section{Preparation}

The cadaver is placed on the table in a supine position. The body, which is derived from the cooler room, should be warmed first by spraying water, then the body is cleaned with antiseptic soap and water. The fecal material should be removed as much as possible from the body by pressing and massage the abdomen.

\section{Embalming solution}

The embalming solution comprises of $7.5 \%$ formalin as the active fixative, glycerin, phenol powder and tap water. Approximately $16 \mathrm{~L}$ fluid is required for embalming one cadaver. The composition is $0.5 \mathrm{~L}$ of glycerin, $500 \mathrm{~g}$ phenol powder in $0.5 \mathrm{~L}$ tap water, $3 \mathrm{~L}$ of $37 \%$ formaldehyde and $12 \mathrm{~L}$ of tap water.

\section{Technique}

The instruments required in embalming process are scalpel, scissors, forceps, artery forceps, $50 \mathrm{~mL}$ syringe pump with $18 \mathrm{G}$ needle and cotton wools. A silicon rubber tube, 2 large arterial cannulae and a $15 \mathrm{~L}$ plastic carboy with metal handle are needed for liquid perfusion to the cadaver.

There are two methods for liquid perfusion: (1) a gravity flow method and (2) a peristaltic pump method. In the gravity flow method, the positive pressure is used to deliver the embalming fluid into the body vessel. The plastic carboy is connected with a pulley, to allow carboy to be elevated or lowered (about 2 meters above the ground level). The spout of the carboy is attached to the silicon rubber tubing, which one side is connected to the $\mathrm{Y}$ or $\mathrm{T}$ connector. One meter tube connected to each the connector and fitted by a cannula in the each distal end of the tube. The preferred method is the use of a peristaltic pump for perfusing the embalming fluid. We can regulate the pressure and the amount of fluid flow as needed, which in our laboratory it is approximately $400 \mathrm{~mL}$ per minute. The pump can be placed on the floor as high as the embalming table and this method finishes quicker than the prior method ( $\pm 1-2$ hour(s) per cadaver).

\section{Embalming the body}

The body is placed in supine anatomical position on the embalming table with abducted position of the upper and lower limb. A thick layer of cotton wool, which is saturated with the embalming fluid, is used to cover all the body orifices except the anus. The container is filled with $15 \mathrm{~L}$ of the embalming fluid.

In the gravity flow method, the plastic carboy is placed about two meters above the surface of the embalming table and tied by the rope. For eliminating the bubble, one pipe is clamped by the cannula, it will cause the embalming fluid flow out of another pipe. Then the same procedure is done for eliminating the bubble from another pipe.

The embalming fluid is delivered into the body via a common carotid artery. First, we incise the skin forward sternocleidomastoid muscle for about three inches and then we dissect carefully with the scalpel cutting out the fascia. We carefully avoid cutting any blood vessels while dissecting. After this, we incise the carotid sheath for about 3 inches down, lift the artery and insert the scalpel handle or forceps under it and separating the artery from the other structure. One small cut, large enough to allow insertion of the cannula is done, then carefully one end of the cannula is inserted and tied with the thread tightly to prevent the cannula from dislogging under pressure. The body now is ready for the infusion of the embalming fluid. 
When the clamp is removed, the gravity will allow the fluid flow slowly. The rate of the flow can be showed approximately by the level of embalming fluid in the container. The flow rate is increased gradually to $400 \mathrm{~mL}$ per minute if there is no obstruction. After approximately 8-10 L of the embalming fluid has been pumped into the body, leakage of fluids from the nose and mouth can be seen. This condition is an indication that the trunk has been filled with the embalming fluid. Further pumping will allows the fluid to perfuse the limbs and the brain. Total time required to infuse 15 $\mathrm{L}$ of the embalming fluid is about 40 minutes. But, we have to consider the size and the physical condition of the body.

After these processes, the body is grayish in colour and the blisters appear in the skin surface, these are the indication of a good perfusion. If there are parts of the body that looked reddish and feel soft, manually injection by the embalming fluid in the $50 \mathrm{~mL}$ syringe should be done locally. Finally the palm of the hand and the sole of the feet are injected too, then the pump is turned off, the cannulae are removed whilst the artery is ligated. All the cotton wools, which saturated with the embalming fluid, are used to cover the body orifices. The body and the embalming table are then hosed down with plenty of water to rinse.

Each body is marked with an engraved number in aluminum sheet that is tied to the wrist and the ankle. Before the cadaver storage, we leave the cadaver on the embalming table over night then next day, we examine the unusual odor and colour of the body parts for indicating the success of the perfusion. If there are areas that feel soft and look reddish, the manual embalming fluid injection is needed locally. This treatment should be repeated for another day. If the body does not show further deterioration, it is ready for the storage. However, if it still has decomposition signs i.e. unusual odor, it should be cremated as soon as possible.

The embalmed body should be stored for six months in the cold room with $4^{\circ} \mathrm{C}$ temperature or in a storage tank filled with solution of 5\% formalin and 5\% glycerin. The purpose is to allow the body preservation and to provide the time for the people who wish to claim the body.

\section{Preparation for cadaver dissection}

Before the practical session, the embalmed body is taken out from the storage room/ tank and placed on the dissecting table. Disinfection of the whole body is conducted with antiseptic soap and then rinsed with plenty of water and left to dry for a day. The body is then put into the new body bag instead of the used one previously. The air conditioner in the dissection hall should be turned on constantly to maintain the temperature at around $4-5^{\circ} \mathrm{C}$ in the refrigerator/ cold room. The exhaust ventilation should only be turned on at the beginning of the practical time because the prolonged exhaustion can increase the humidity of the hall and enabled the growth of fungi.

At the end of practical class, each exposed area or organ of the cadaver are applied with solution of $1.8 \mathrm{~L}$ glycerin, $0.2 \mathrm{~L}$ pine oil and $1.5 \mathrm{~L}$ tap water to maintain the tissue moist and prevent the fungal growth.

\section{RESULTS}

Cadaver processed by low formalin technique showed lighter coloration thus morphology and structure details i.e. muscles, neurovascular and internal organs are easier to be observed and to be studied when compared to those processed by high formalin technique (Figures $1 \mathrm{a}-\mathrm{b})$. The consistency of muscles and internal organs of the cadaver processed by low formalin technique is more elastic and drier whilst stay moist than cadaver processed by high formalin technique that appears darker, wet in formalin solution and often structures are hardly differentiated one to another. All in all, the appearance and details of cadaver processed by low formalin technique are better for anatomy teaching and learning when compared to those processed by high formalin technique.

\section{DISCUSSION}

Better quality of cadaver has been produced from the use of low formalin technique when compared to the use of high formalin solution. In terms of structures i.e. vessels, muscles and nerves become more visible with paler colour resulted with no fungal growth observed. Intact luminal structures including vessels can be achieved with higher rate when compared of using the high formalin technique $(37 \%)$ due to more diluted embalming solution in low-formalin technique (5-7.5\%). Clearer in coloration of cadaver structures are conjoined with good consistency of structures such as elasticity of muscles are still preserved relatively when compared to the high-formalin technique. These were achieved whilst the adverse effect of formalin to the staff, technicians and students were lower in the low-formalin technique when compared to in high-formalin technique. Lower price is also another advantage of using this technique, in regards to lower formalin used in the embalming solution means lower in total volume. 
(a)

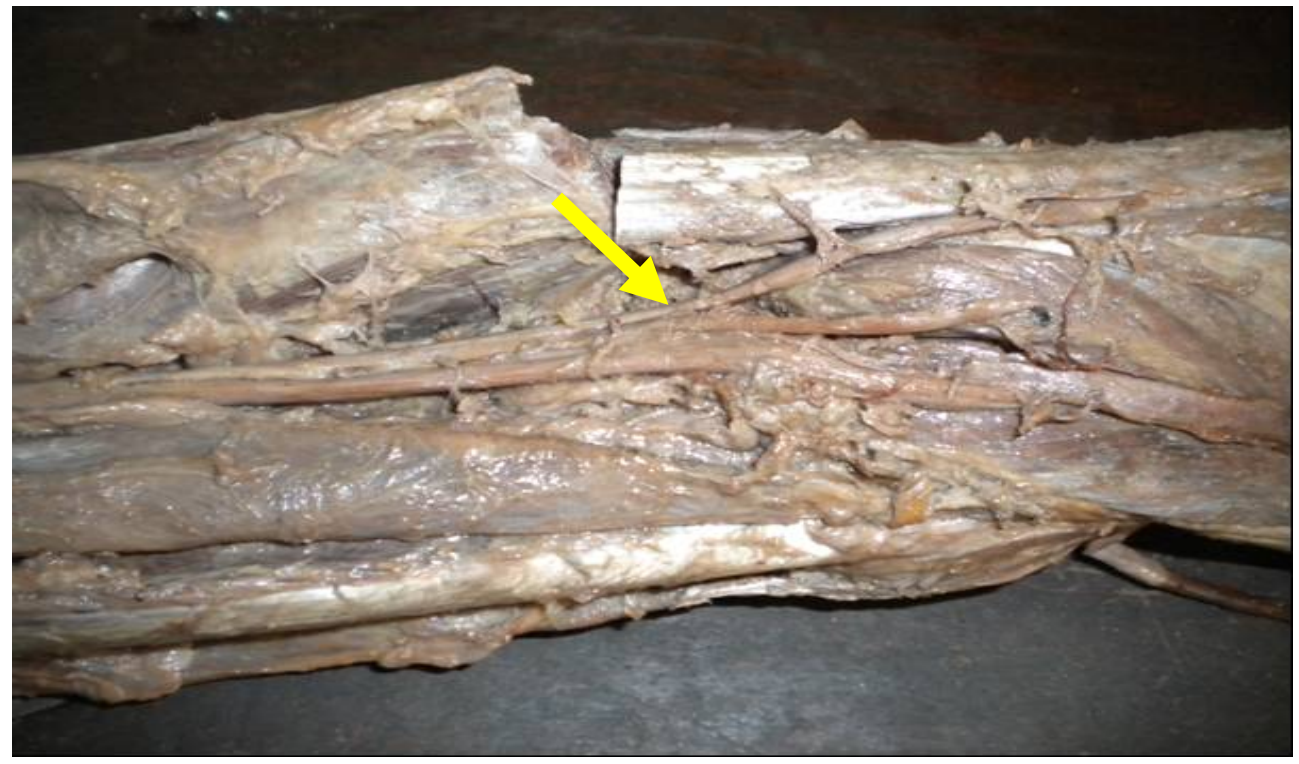

(b)

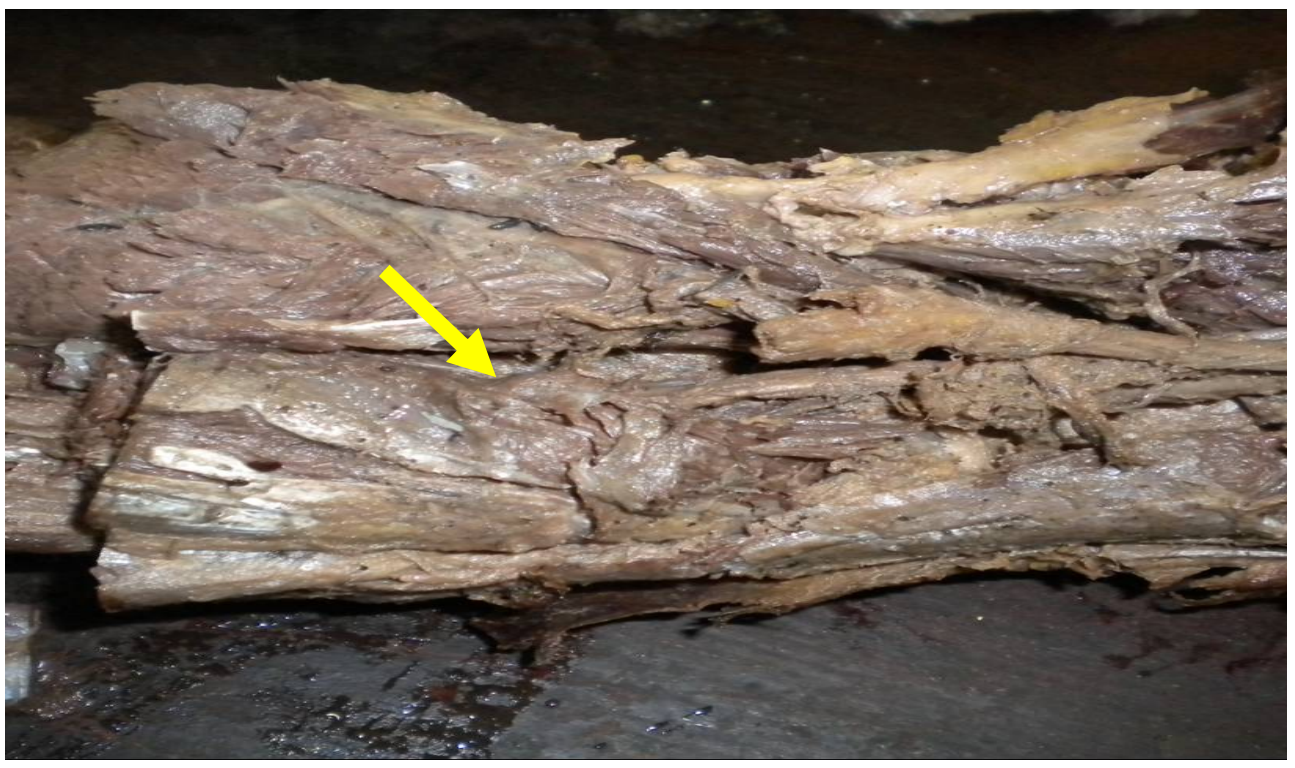

Figure 1. Anatomy cadaver is dissected to show content of fossa poplitea. (a) Cadaver processed by low formalin embalming technique showed intact, more visible arterial structure and its branches [yellow arrow] with paler coloration of vessel, nerves and muscles, and relatively good consistency when compared to (b) cadaver processed by high formalin embalming technique (all rights belong to Department of Anatomy and Histology, Faculty of Medicine, Airlangga University, Surabaya, Indonesia)

Low formalin embalming technique has been developed in several laboratories due to high risk of using high percentage of formalin to embalm the cadaver. ${ }^{8,9,10}$ The prior technique ensures the formalin containing air inside the practical room much lower than the later technique. ${ }^{1,11}$ The carcinogenic effect of formalin and phenol used in the embalming solution can be decreased by using the low formalin technique.,, 7

The time used in low formalin technique is quicker to that of high formalin technique, better the prior technique is slightly quicker due to more diluted solution entered the vessels of the cadaver faster (approximately 30 minutes quicker when compared to using a higher formalin-containing solution). The risk of vessel rupture can also diminished (Figure 1).

If the low formalin technique is applied appropriately, and the cadaver produced is stored properly, many advantageous can be regained as mentioned above. Despite risks of fungal growth on embalmed cadaver in tropical weather like in Indonesia, we proved that 
this problem can be limited by doing this technique accordingly.

In conclusion, low formalin technique for embalming cadaver for anatomy speciment is a visible and advantageous technique to produce specimens for anatomy dissection due to lower health risk to the lecturers, technicians and students and relatively less expensive technique when compared to the plastination. The aftercare procedures are also relatively uncomplicated by the use of pump machine (similar to the older technique), whilst the produce is in a better quality to study the morphology in anatomy practices.

\section{Acknowledgments}

We would like to thank Head and staff of Department of Anatomy and Histology, Faculty of Medicine, Airlangga University, Surabaya for all support given. We thank Prof. Gopalakhrisnakone, FAMS, DSc, PhD, MBBS, MD and staff of Department of Anatomy, School of Medicine, National University of Singapore for advices and support in developing the methods.

\section{REFERENCES}

1. Coleman R, Kogan I. An improved low-formaldehyde embalming fluid to preserve cadavers for anatomy teaching. J Anat. 1998;192:443-6.
2. O'Sulivan E, Mitchell BS. An improved composition for embalming fluid to preserve cadaver for anatomy teaching in the United Kingdom. J Anat. 1993;182:295-7.

3. Saeed M, Rufai AA, Elsayed SE. Mummification to plastination. Saudi Med J. 2001;22(11):965-9.

4. Moore CM, Brown CM. Gunther von Hagens and body worlds part 1: the anatomist as prosektor and proplastiker. Anat Rec B New Anat. 2004;276(1):8-14.

5. von Hagens G, Tiedemann K, Kriz W. The current potential of plastination. Anat Embryol (Berl). 1987; 175(4):411-21

6. McQuillan PM, LeGrande Y, Wade R. Use of plastinated human specimens in teaching regional anesthetic techniques. International Journal of Plastination. 1994;8(1):15-8

7. Dixit D, Athavia PD, Pathak HM. Toxic effects of embalming fluid on medical students and professionals. JIAFM. 2005;27(4):209-11.

8. Whitehead MC, Savoia MC. Evaluation of methods to reduce formaldehyde level of cadavers in the dissection laboratory. Clin Anat. 2008;21(1):75-81.

9. Anderson SD. Practical light embalming technique for use in the surgical fresh tissue dissection laboratory. Clin Anat. 2006;19(1):8-11.

10. Levine RL, Kieves S, Cathey G, Blinchevsky A, Acland R, Thompson R, et al. The use of lightly embalmed (fresh tissue) cadavers for resident laparoscopic training. J Minim Invasive Gynecol. 2006;13(5):451-6.

11. Paustenbach D, Alarie Y, Kulie T, Scahchter R, Smith N, Swenberg J, et al. A recommended occupational exposure limit for formaldehyde based on irritation. J Toxicol Environ Health.1997;50(3):217-63. 